I

\title{
ResearchArticle
}

\section{Management of wilt and dry root rot diseases of redgram [Cajanus cajan (L.) Millsp.] by using actinomycetes}

\author{
S. Malathi
}

\section{SUMMARY}

Actinomycetes were tested for their antagonistic activity against Fusarium udum and Macrophomina phaseolina under in vitro condition. Among the tested isolates of Actinomycetes AC (5) reported highest 82.85 per cent reduction of mycelial growth of Fusarium udum and 85.13 per cent reduction of mycelial growth of Macrophomina phaseolina. In the field experiment, five treatments were tested for the management of wilt and dry root rot disease, $\mathrm{T}_{3}-\mathrm{ST}+\mathrm{SA}$ with Actinomycetes (AC 5) significantly recorded 71.92 and 70.38 per cent reduction of the wilt and dry root rot diseases, respectively. These biocontrol agents were used an alternative to the chemical fungicide for controlling the wilt and dry root rot incidence and enhanced the plant growth parameters and there by increased yield in redgram.

Key Words : Redgram, Fusarium udum, Macrophomina phaseolina, Actinomycetes, Management

How to cite this article : Malathi, S. (2020). Management of wilt and dry root rot diseases of redgram [Cajanus cajan (L.) Millsp.] by using actinomycetes . Internat. J. Plant Sci., 15 (2): 96-100, DOI: 10.15740/HAS/IJPS/15.2/96-100, Copyright@ 2020: Hind AgriHorticultural Society.

Article chronicle : Received : 24.04.2020; Revised : 19.05.2020; Accepted : 05.06.2020 